\title{
"SUAS IDEIAS NÃO CORRESPONDEM AOS FATOS": O CONVENIAMENTO NA EDUCAÇÃO INFANTIL COM ORGANIZAÇÕES DA SOCIEDADE CIVIL NO ESTADO DO RIO DE JANEIRO E NA BAIXADA FLUMINENSE
}

\author{
"Your ideas do not correspond to the facts": the partnership in child education with Civil Society \\ Organizations in Rio de Janeiro state and the Baixada Fluminense.
}

\begin{abstract}
"Sus ideas no se corresponden con los hechos": el acuerdo en la educación infantil con Organizaciones de la Sociedad Civil en el estado de Rio de Janeiro y en Baixada Fluminense.
\end{abstract}

Received: $\operatorname{may} / \mathbf{2 0 2 0}$

Accepted: september/2020

Available online: september/2020

Edson Cordeiro dos Santos, Doutor em Educação (Unirio), Pós-Doutorando pela Pontifícia Universidade Católica do Rio de Janeiro - PUC-Rio/Capes, Brasil. E-mail: edsoncordeiro.nig@gmail.com

\begin{abstract}
Resumo: O artigo analisa a implementação da política pública na Educação Infantil (EI) por meio de parceria com Organizações da Sociedade Civil, no estado do Rio de Janeiro (ERJ) e na Baixada Fluminense (BF), entre 2008 e 2019. A opção metodológica é a pesquisa empírica, utilizando pesquisa documental e bibliográfica e construção de informações com tratamento de dados primários. Apresenta o histórico do atendimento à etapa; estabelece o contexto da investigação; e analisa a política de conveniamento. Estudos apontam que a ampliação do acesso à EI ocorre a partir de parcerias do poder público com instituições de fins não-econômicos. Dos 92 municípios do ERJ, em 2008, 36 realizaram convênios, retrocedendo, em 2019, para 34. Nos 13 municípios da BF, partiu de 2, em 2008, chegando a 6 em 2019. Observamos no ERJ aumento de 53,6\% nas matrículas por convênios e na BF 164,6\%, no período. O universo das matrículas da etapa em 2018 (creches e pré-escolas) é de 619.058 no ERJ e 105.389 na BF, com a percentagem de matrículas conveniadas representando 5,6\% (34.884) e 3,2\% (3.399), respectivamente. A despeito das impressões gerais, a ampliação vem se dando com o aumento do atendimento municipal, contando com suporte da rede privada, em especial, das unidades particulares com fins lucrativos.
\end{abstract}

Palavras-chave: Educação Infantil, Organização da Sociedade Civil, Parceria Público-Privada. 


\begin{abstract}
The paper analyses the implementation of the public policy in Child Education (EI) through the partnership with Civil Society Organizations, in the state of Rio de Janeiro (ERJ) and the Baixada Fluminense (BF), between 2008 and 2019. The methodological option is the empirical research, using documental and bibliographical research and the construction of information with treatment of primary data. Presents the history of service to the stage; establishes the context of the investigation; and analyzes the policy of partnership. Studies indicate that the increased access to EI occurs due to partnerships of the public power with institution with non-economic purposes. Of 92 cities in the ERJ, in 2008, 36 formed partnerships, receding in 2019, to 34. In the 13 cities in the BF, it increased from 2, in 2008, to 6 in 2019. We observed in ERJ enrollment in partnerships increased $53.6 \%$ and in BF increased $164.6 \%$ in the period. The universe of enrollment in the stage in 2008 (in day-care and pre-school) is 619058 in ERJ and 105389 in BF, with the percentage of enrollment in partnerships representing $5.6 \%$ (34884) and $3.2 \%$ (3399), respectively. Despite general impression, the extension is due to the increase in municipal attendance, counting on support from the private network, especially private units with economic purposes.
\end{abstract}

Keywords: Child Education, Civil Society Organization, Public-Private Partnerships.

Resumen: El artículo analiza la implementación de las políticas públicas en Educación Infantil (EI) a través de una asociación con organizaciones de la sociedad civil, en el estado de Río de Janeiro (ERJ) y en Baixada Fluminense (BF), entre 2008 y 2019. La opción metodológica es la investigación empírica, en la cual se utiliza la investigación documental y bibliográfica y la construcción de información con tratamiento de datos primarios. Presenta la historia de asistencia a la etapa de la EI; establece el contexto de investigación; y analiza la política del acuerdo. Los estudios señalan que la expansión del acceso a la EI ocurre a través de asociaciones entre las autoridades públicas y las instituciones sin fines de lucro. De los 92 municipios del ERJ, en 2008, 36 hicieron acuerdos, volviendo, en 2019, a 34. En los 13 municipios de BF, comenzó desde 2, en 2008, llegando a 6 en 2019. Se observa en el ERJ un aumento del $53,6 \%$ en las inscripciones por acuerdo y en la BF 164,6\%, en el período. El universo de inscripciones para la etapa en 2018 (guarderías y preescolares) es de 619.058 en el ERJ y 105.389 en la BF, con un porcentaje de inscripciones de acuerdo que representa 5,6\% (34.884) y 3,2\% (3.399), respectivamente. A pesar de las impresiones generales, la expansión se produjo con el aumento del servicio municipal, con el apoyo de la red privada, en particular, de las unidades privadas con fines de lucro.

Palabras clave: Educación Infantil, Organización de la Sociedad Civil, Asociación Público-Privada.

\title{
INTRODUÇÃO
}

"Uma política tem uma trajetória semelhante à de um foguete: decola, atravessa o espaço e depois aterrissa. Algumas vezes, acidenta-se; em outras, atinge uma realização espetacular, mas move-se através do tempo, e, algumas vezes, simplesmente desaparece. As políticas desaparecem no decorrer do tempo ou, algumas vezes, leva muito tempo para elas se tornarem integradas. Algumas vezes, elas são apressadas ou atrasadas. É necessário pensar sobre a velocidade das políticas, é necessário ter a dimensão do tempo, bem como do espaço" (BALL, 2009, p. 307).

O presente artigo analisa a implementação da política pública na Educação Infantil (EI) por meio da estratégia de parceria com Organizações da Sociedade Civil (OSCs) ${ }^{1}$, no estado do Rio de 
Janeiro (ERJ) e na Baixada Fluminense (BF), baseado, principalmente, em estudos, acervos e achados de pesquisas que discorrem sobre a etapa educacional atravessados pela temática do conveniamento $^{2}$. A principal questão de pesquisa é identificar se a ampliação do acesso das crianças à EI ocorreu no âmbito público ou a partir de parcerias, sendo formulada da seguinte forma: "são utilizadas matrículas conveniadas na EI em larga escala com o fito de ampliar o acesso das crianças nesta etapa?".

A opção metodológica foi a pesquisa empírica, que utiliza para a obtenção de dados a pesquisa documental e bibliográfica e a construção, a partir do tratamento de dados primários, de informações necessárias à análise aprofundada sobre o acesso das crianças à creche e à pré-escola por meio do conveniamento, em especial, os dados das instituições consideradas nos recursos do Fundo de Manutenção e Desenvolvimento da Educação Básica e Valorização dos Profissionais da Educação - Fundeb ${ }^{3}$, disponibilizados pelo Fundo Nacional de Desenvolvimento da Educação FNDE $^{4}$. O mencionado Fundo disponibiliza anualmente, desde 2008, uma planilha contendo informações de todos os estados da Federação. Na planilha constam, em colunas, os estados da Federação, os diversos municípios de cada estado, o nome da entidade, o segmento atendido (creche em tempo integral, creche em tempo parcial, creche em Educação Especial, pré-escola em tempo

\footnotetext{
${ }^{1}$ Atualmente o termo genérico ONG - Organização Não-Governamental foi substituído por Organização da Sociedade Civil - OSC pela Lei Federal $n^{\circ}$. 13.019/2014 (BRASIL, 2014b), que estabelece o novo marco legal para o Terceiro Setor brasileiro.

${ }^{2}$ Os termos "convênio", "conveniada" e "conveniamento", serão utilizados de forma corrente neste artigo, dada a sua centralidade no imaginário do Movimento de Luta por Creches, em especial, pelas instituições comunitárias, filantrópicas e confessionais que buscavam, ao longo do tempo, um relacionamento efetivo com o Poder Público (ver SANTOS, 2013). Porém, a Lei citada na Nota anterior determina que a relação da OSC com o poder público se estabelece a partir de "parceria", por meio de "termo de colaboração", "termo de fomento" ou "acordo de cooperação".

${ }^{3}$ É um fundo especial, de natureza contábil e de âmbito estadual (um fundo por estado e Distrito Federal, num total de vinte e sete fundos), formado, na quase totalidade, por recursos provenientes dos impostos e transferências dos estados, Distrito Federal e municípios, vinculados à educação por força do disposto no art. 212 da Constituição. Disponível em: $<$ https://www.fnde.gov.br/financiamento/fundeb $>$. Acesso em: 4/set./2020. O Fundo tinha validade até o ano de 2020, contudo, com tramitação desde o ano de 2015 no Congresso Nacional, foi aprovado o novo Fundeb no dia 25/8/2020 (Emenda Constitucional 108/2020), agora passando a ser permanente e ampliando percentuais dos recursos destinados ao setor pela União. Fonte: Agência Senado. Disponível em: $<$ https://www12.senado.leg.br/noticias/materias/2020/08/25/novo-fundeb-sera-maior-e-tera-carater-permanente>. Acesso em: 6/set./2020.

${ }^{4}$ Autarquia federal criada pela Lei no $.5 .537 / 1968$ (BRASIL, 1968), e alterada pelo Decreto-Lei no ${ }^{\circ}$ 872/1969 (BRASIL, 1969), é responsável pela execução de políticas educacionais do Ministério da Educação (MEC). Disponível em: $<$ https://www.fnde.gov.br/index.php/acesso-a-informacao/institucional $>$. Acesso em: 4/set./2020.
} 
integral, pré-escola em tempo parcial, pré-escola em Educação Especial etc.), o número de estudantes de cada segmento atendido, a categoria da entidade (comunitária, filantrópica ou confessional) e o tipo de convênio (estadual ou municipal). Para dimensionarmos a empreitada, temos, por exemplo, que a planilha do ano de 2019 possui quase 12 mil linhas, sendo, em média, as mesmas nos 12 anos estudados. De posse da Planilha Geral anual, selecionamos a parte referida ao ERJ, equivalendo, em média, cerca de 600 linhas. Confeccionamos uma Planilha Própria (Excel), contendo as seguintes colunas: Mesorregiões, Microrregiões, Municípios e para cada ano: Dados da creche (Parcial, Integral e Educação Especial, Total), Dados da pré-escola (Parcial, Integral e Educação Especial, Total) e Total Geral. Transferimos os dados numéricos da Planilha Geral para a Planilha Própria, sendo possível contabilizarmos os dados ano-a-ano em todas as suas especificidades e territórios. Demo $\left(1985\right.$, p. 25) considera como pesquisa empírica ${ }^{5}$ aquela voltada, sobretudo, para a face experimental e observável dos fenômenos, manipulando dados e fatos concretos, que, segundo ele, "procura traduzir os resultados em dimensões mensuráveis." O autor acentua que o valor deste tipo de abordagem metodológica é o de trazer a teoria para a realidade concreta, advertindo que "se levarmos em conta somente o mensurável, ficaremos com o superficial. Mas, se soubermos usar, a dedicação empírica chega a ser um remédio para as ciências sociais.” (DEMO, 1985, p. 26). A abordagem do trabalho foi a pesquisa mista (qualiquantitativa), com levantamento de dados primários e secundários, análise documental, com tratamento de dados e revisão de literatura sobre o tema.

Entendemos a política pública como um conjunto de medidas e decisões que guiam e/ou definem ações de Estado. Assim, a política pública de EI é analisada a partir de sua trajetória política e da aprovação de pressupostos legais que orientam esta etapa educacional no Brasil, tais como, a obrigação legal de atendimento pelo Estado e o direito subjetivo para as crianças de 4 e 5

\footnotetext{
${ }^{5}$ Demo (1985) distingue quatro linhas básicas de pesquisa, além da empírica já mencionada, a teórica, a metodológica e a prática. Resumidamente temos que a pesquisa teórica é aquela que monta e desvenda quadros teóricos de referência; a pesquisa metodológica não se refere diretamente à realidade, mas aos instrumentos de captação e manipulação dela; e a pesquisa prática é aquela que se faz através do teste prático de possíveis ideias ou posições teóricas.
} 
anos, a partir da Emenda Constitucional (EC) nº. 59/2009 (BRASIL, 2009a), referendada pela Lei $\mathrm{n}^{\circ}$. 12.796/2013 (BRASIL, 2013). É de relevância proceder tal estudo a partir da inclusão da EI como primeira etapa da Educação Básica (EB), oferecida em creches e em pré-escolas, com obrigatoriedade do segundo segmento mencionado.

Percebemos a suma importância dos avanços na legislação e como afeta à EI, mas, também temos claro que foram cruciais as lutas engendradas ao longo do tempo por diversos atores, tanto da esfera pública como da sociedade civil. Temos ainda que, no Brasil, a efetivação das conquistas políticas não acontece de forma imediata após a aprovação da lei, ou seja, é necessária uma luta para a sua conquista e a batalha continua para a sua efetivação. Para Santos (2009), as políticas públicas representam um dos principais resultados da ação do Estado, entretanto, não são uma exclusividade do Estado, envolvem também uma gama de outras instituições e movimentos. Muitas vezes, a iniciativa da formulação de uma política pública não parte do Estado, mas consiste em ação estabelecida por instituições não-estatais. Assim, Santos (2013), complementa dizendo que, no caso da política pública de EI, a responsabilidade foi e é compartilhada por atores públicos, privados e da sociedade civil, inclusive, em sua implementação.

No estudo desenvolvido por Santos (2009), se rejeita a abordagem que coloca o Estado como único ator relevante no processo das políticas públicas, trazendo-as, no contexto de alta complexificação das sociedades contemporâneas, como resultado de interação entre agências estatais e organizações não-estatais. O autor adensa que "nesse caso, se por um lado a execução das políticas tem a capacidade de, potencialmente, ganhar em eficiência, por outro lado, tem o efeito de introduzir novos elementos a desafiar a legitimação democrática da autoridade pública." (SANTOS, 2009, p. 63). De acordo com o autor, o que está em jogo não é a falência do Estado, como aparece em algumas interpretações, “mas, ao contrário, de um cenário em que instituições das distintas esferas da sociedade assumem crescentemente papéis relevantes na produção de políticas públicas.” (SANTOS, 2009, p. 63). Contudo, o autor alerta que tal processo apresenta seus desafios, pois os 
atores não-estatais, mesmo identificados como portadores de recursos relevantes, com conhecimentos e com soluções para as situações-problemas, não são submetidos aos mesmos mecanismos de legitimação democrática utilizados para boa parte das instituições estatais.

$\mathrm{O}$ artigo estrutura-se da seguinte forma: primeiro, traz o histórico do atendimento à primeira infância no Brasil, no ERJ e na BF, consubstanciado pela criação de um sólido marco legal; segundo, estabelece o contexto da investigação, com dados dos territórios mencionados; terceiro, analisa a política de conveniamento tanto no estado como na região estudada e, por fim, tece algumas considerações.

\section{A política pública de Educação Infantil}

Em relação à política de atendimento à criança pequena, temos que a mesma percorreu uma longa trajetória histórica, podendo ser resgatada, por exemplo, nos anos 1700, com a "Roda dos Expostos", que era um mecanismo utilizado como alternativa de acolhimento à infância, em especial, às mais pobres e abandonadas (LOSACCO, 2011), ou após a "independência", em 1822, e as sucessivas legislações pensadas, elaboradas e algumas até aprovadas (SAVIANI, 2007). Em termos de atendimento na EI, apontamos a criação de "jardins de infância” a partir dos anos 1870, sob a influência de experiências europeias, que atendiam, em geral, os filhos das famílias abastadas. As referências ao termo "creche" também aparecem no período mencionado (KUHLMANN JÚNIOR, 1991; CIVILETTI, 1991).

Com o processo de industrialização em curso no Brasil, o atendimento à criança pequena também passa a ser uma preocupação nas décadas finais do século XIX e início do século XX, registrando-se a criação de “creches" nas indústrias, para atender às mães trabalhadoras. Além das “creches" mencionadas, também são criadas as "creches assistencialistas", ligadas a instituições filantrópicas (KUHLMANN JÚNIOR, 1991). No início do século XX o atendimento à criança, em 
especial, a partir da recém "abolição da escravatura no Brasil" e da "violência crescente", passou a ser também influenciada pelo conceito jurídico-policial, com, por exemplo, a criação de creches em "Patronatos de Menores", para a "infância moralmente abandonada" (KUHLMANN JÚNIOR, 1991).

A partir dos anos 1940, o atendimento de crianças e de adolescentes pobres passou a ser visto como uma forma de enquadrá-los às boas normas sociais, como, por exemplo, a criação do Serviço de Assistência ao Menor - $\mathrm{SAM}^{6}$ (1941), vinculado ao Ministério da Justiça e Negócios Interiores, para atender “menores abandonados". Também nesse período, mencionamos a criação da Legião Brasileira de Assistência - LBA7 e as instituições do Sistema "S"8 (1942), que, juntamente com entidades religiosas de várias confissões, prestavam atendimento às crianças "carentes", tais como, cursos e auxílios financeiros. Nunes, Corsino e Didonet (2011) nos trazem a elaboração da Consolidação das Leis do Trabalho (CLT) ${ }^{9}$, no ano de 1943, que incluía como determinação para os estabelecimentos comerciais, industriais, agrícolas e de serviços, nos quais trabalhassem pelos menos 30 mulheres com idade acima de 16 anos, que mantivessem um local apropriado para a guarda sob vigilância e assistência de seus filhos no período de amamentação. Anotamos também nesse período a criação do Fundo das Nações Unidas para a Infância (Unicef) ${ }^{10}$, em 1946, órgão

\footnotetext{
${ }^{6}$ Primeiro órgão federal a se responsabilizar pelo controle da assistência aos menores em escala nacional, atendendo os "menores abandonados" e "desvalidos", encaminhando-os às instituições oficiais existentes, e os "menores delinqüentes", internando-os em colônias correcionais e reformatórios. Disponível em: $<$ http://crianca.mppr.mp.br/pagina-2174.html>. Acesso em: 4/set./2020.

${ }^{7} \mathrm{~A}$ LBA foi a primeira instituição assistencial de porte nacional, inclusive, realizando convênios com instituições de fins não-econômicos, sendo extinta em 1995, no primeiro dia de governo de Fernando Henrique Cardoso.

${ }^{8}$ Termo que define o conjunto de organizações das entidades corporativas voltadas para o treinamento profissional, assistência social, consultoria, pesquisa e assistência técnica, que além de terem seu nome iniciado com a letra S, têm raízes comuns e características organizacionais similares. Fazem parte do sistema S: Senai; Sesc; Sesi; Senac; Senar; Sescoop; e Sest. Fonte: Agência Senado. Disponível em: $<$ https://www12.senado.leg.br/noticias/glossario-legislativo/sistema-s>. Acesso em: 4/set,./2020.

${ }^{9}$ Sancionada pelo então presidente Getúlio Vargas, unificando toda legislação trabalhista existente no Brasil, tendo como objetivo a regulamentação das relações individuais e coletivas do trabalho, nela previstas. Disponível em: < http://www.guiatrabalhista.com.br/tematicas/clt.htm>. Acesso em: 4/set./2020.

${ }^{10}$ É uma instituição originária da Organização das Nações Unidas; que tem como meta proteger os direitos infantis, procurar oferecer soluções às suas carências elementares e promover seu desenvolvimento integral. Disponível em: $<$ https://www.infoescola.com/geografia/unicef/>. Acesso em: 4/set./2020.
} 
ligado à Organização das Nações Unidas $(\mathrm{ONU})^{11}$, que atuava por meio de convênios com órgãos governamentais da esfera federal, estadual e municipal (FREIRE; SIMÕES, 2001).

Junto com a ditadura civil-militar, a Assistência separa-se da Justiça, com a substituição do SAM pela Fundação Nacional de Bem-Estar do Menor - Funabem ${ }^{12}$ (1964), subordinada diretamente ao Presidente da República no ato de criação, com implementação de fundações similares nos estados (Febems). De certa forma, a Assistência continuava a cargo da LBA e instituições similares, que funcionavam, inclusive, como apoio financeiro à Política Nacional de Bem-Estar do Menor, em forte parceria e com apoio jurídico da autoridade competente (“Juizado de Menores”) (CABRAL, 1982). No ERJ, que na época era dividido em dois estados, foram criadas a Febem - Fundação Estadual do Bem-Estar do Menor (do antigo estado da Guanabara) e a Flubem Fundação Fluminense do Bem-Estar do Menor (do antigo estado do Rio de Janeiro). Com a fusão dos dois estados, em 1975, ocorreu a fusão das duas fundações, com a criação da Feem - Fundação Estadual de Educação do Menor ${ }^{13}$. Apesar da inclusão no nome da palavra "educação", a mesma continuou ligada aos princípios previstos pela política nacional desenvolvida pela Funabem. A partir de 1979, conforme já vinha fazendo a LBA, a Feem passou a contratar serviços de entidades particulares para firmar convênios, utilizando para tanto os recursos e equipamentos sociais existentes nas comunidades. Assim sendo, têm-se notícias de que estes convênios foram firmados com diversas entidades dos municípios do ERJ, incluindo os da BF. Estes convênios foram firmados até 1996 (SANTOS, 2013).

\footnotetext{
${ }^{11}$ É uma organização internacional criada no pós-guerra e que tem como principal objetivo garantir a paz no mundo. Com sede em Nova Iorque, atualmente, a ONU conta com 192 Estados membros. Disponível em: $<$ https://www.infoescola.com/geografia/organizacao-das-nacoes-unidas-onu/>. Acesso em: 4/set./2020.

${ }^{12}$ Criada junto com a Política Nacional do Bem-Estar do Menor (PNBEM), que deveria coordenar todas as ações na área. A questão da infância passou a ser tratada como problema de segurança nacional e deu origem às Febems em nível estadual. Disponível em: <http://crianca.mppr.mp.br/pagina-2174.html >. Acesso em: 4/set./2020.

${ }^{13}$ Com a aprovação do Estatuto da Criança e do Adolescente - ECA, em 1990 (BRASIL, 1990), a legislação de atendimento às crianças e adolescentes no ERJ é adequada, em especial, pela substituição da nomenclatura "menor", muito ligada à "situação irregular" prevista no Código de Menores (1927, reformulado em 1979). Assim, a Feem passou a ser denominada como Fundação Recanto, em 1990, e, nos meados dos anos 1990, passou a ter a denominação que permanece até os dias atuais: Fundação para a Infância e Adolescência - FIA. Com as novas atribuições estabelecidas pelo ECA, a FIA foi redirecionando o trabalho que havia sido desenvolvido nos anos anteriores, entre eles as parcerias com as creches e pré-escolas comunitárias, que só permaneceu até o ano de 1996.
} 
No final dos anos 1970 ocorre a eclosão do Movimento de Luta por Creche (MLC), que, encabeçado por mulheres trabalhadoras de grandes centros urbanos, passou a ser pautado pelos meios de comunicação e exercer pressão sobre o governo. Esse movimento ganhou força e expandiu-se por todo o país, chegando dessa forma ao ERJ e à região estudada por este trabalho (BF), estando presente até hoje por meio das “instituições sem fins lucrativos" que atuam nas demandas sociais pela EI. Também ganham visibilidades no cenário nacional diversas iniciativas governamentais, tais como, o Projeto Casulo da LBA ${ }^{14}$ (1974), a criação da Coepre - Coordenação de Educação Pré-Escolar ${ }^{15}$ (1975) e o lançamento do Programa Nacional de Educação Pré-Escolar ${ }^{16}$ (1981) (NUNES; CORSINO; DIDONET, 2011 e FREIRE; SIMÕES, 2001).

No final dos anos 1980 temos a aprovação da Constituição Federal de 1988 - CF/1988 (BRASIL, 1988) e a posterior aprovação, na década seguinte, de diversas leis regulamentadoras e modificativas, tais como, a Lei de Diretrizes e Bases da Educação Nacional - LDB, em 1996 (BRASIL, 1996), que confirma a EI como a primeira etapa da educação básica, sendo oferecida em creches (crianças até três anos) e em pré-escolas (crianças de quatro e cinco anos), constituída como incumbência dos municípios.

Os anos 2000 trazem como novidade a discussão do financiamento da EI, com a aprovação da Emenda Constitucional (EC) n ${ }^{\circ}$. 53/2006 (BRASIL, 2006) que cria o Fundeb, com posterior regulamentação: Lei Federal nº. 11.494/2007 (BRASIL, 2007a) e Decreto nº. 6.253/2007 (BRASIL, 2007b). Ressalte-se que, apesar de toda a legislação educacional construída até aquele momento, a proposta de EC enviada pelo Poder Executivo ao Congresso Nacional não incluía as creches. A luta

\footnotetext{
${ }^{14} \mathrm{O}$ Projeto atendia crianças de 0 a 6 anos de idade e tinha a intenção de proporcionar às mães tempo livre para poder "ingressar no mercado de trabalho e, assim, elevar a renda familiar". Disponível em: $<$ https://monografias.brasilescola.uol.com.br/pedagogia/a-historia-das-creches.htm>. Acesso em: 4/set./2020.

${ }^{15}$ A Coordenação tinha como objetivo incentivar as Secretarias de Educação a criarem as Coordenações voltadas à pré-escola nos estados. Disponível em: <https://www.passeidireto.com/arquivo/5271098/gest-o-da-educa-o-infantil/2>. Acesso em: 4/set./2020.

${ }^{16}$ Uma das estratégias do Programa era realizar convênios entre as Secretarias Estaduais de Educação e o MEC/Coepre, com a prioridade de expandir a pré-escola de baixo custo, em grandes espaços (100 e 120 crianças), utilizando mães voluntárias.
} 
pela inclusão da creche no Fundeb teve muito envolvimento das instituições comunitárias que atuavam na EI, tanto no ERJ como da BF, pois, viam, além da inclusão da creche na política de financiamento, a possibilidade de inclusão dos convênios numa política de caráter nacional. $\mathrm{O}$ Fundeb prevê que todas as matrículas em estabelecimentos de EI da rede municipal, inclusive das unidades privadas sem fins lucrativos conveniadas com o poder público, tenham o direito de receber determinado valor educando/ano para sua manutenção.

No ano de 2009 foi aprovada a EC nº. 59/2009 (BRASIL, 2009a), que, entre outras deliberações, coloca a educação pré-escolar (4 e 5 anos de idade) como direito subjetivo, ou seja, como educação obrigatória, com universalização prevista até 2016, referendada, posteriormente, pela aprovação da Lei $\mathrm{n}^{\circ}$. 12.796/2013 (BRASIL, 2013). A discussão sobre a obrigatoriedade teve espaço privilegiado de discussão tanto na Conferência Nacional de Educação (2010) quanto na tramitação do novo PNE no Congresso Nacional - Lei nº 13.005/2014 (BRASIL, 2014a).

O ERJ acompanha e participa de todas as mudanças oferecidas pela legislação consolidada nacionalmente. No ano de 1998, um ano antes do término do prazo para que as instituições de EI vinculassem a um sistema de ensino, o Conselho Estadual de Educação do Estado do Rio de Janeiro (CEE/RJ) aprovou a Deliberação $\mathrm{n}^{\circ}$. 231/1998 (RIO DE JANEIRO, 1998), modificada pela Deliberação CEE n’. 244/1999 (RIO DE JANEIRO, 1999a), que "fixa normas para autorização de funcionamento de instituições privadas de Educação Básica (EB) e dá outras providências”, contudo, desconsiderando as instituições de ensino de fins não-econômicos (comunitárias, confessionais e filantrópicas) ${ }^{17}$, que existiam em grande número no estado. Após discussões no referido Conselho, com os esclarecimentos sobre as diferenças entre as "instituições particulares" e “instituições comunitárias”, foi aprovada a Deliberação n. 245/1999 (RIO DE JANEIRO, 1999b), incluindo as categorias previstas na LDB e criando a denominação de Centros de Educação Infantil

\footnotetext{
${ }^{17}$ Este entendimento era dado pelo artigo 20 da LDB, que foi revogado pela Lei no ${ }^{\circ}$. 13.868/2019. A referida Lei incluiu as instituições comunitárias no inciso III do artigo 19, prevendo em seus parágrafos, também inclusos, que as instituições privadas e comunitárias podem se qualificar como confessionais, também podendo se certificar como filantrópicas.
} 
Comunitários - Ceics, que passou a ser utilizada pela maioria das unidades de EI comunitárias a partir de então no ERJ. Na década seguinte, os sistemas próprios foram sendo criados pelos municípios, gerando deliberações específicas para a EI.

$\mathrm{Na}$ BF a luta pela implementação da EI se intensificou por volta dos anos 1970, visando resolver os problemas básicos das crianças das camadas empobrecidas e possibilitando que as mães pudessem permanecer ou ingressar no mercado de trabalho, surgindo em um momento em que os movimentos populares lutavam por melhores condições de vida para a população. Diversas instituições e movimentos passaram a lutar e a organizar, em espaços comunitários existentes (associações, igrejas, casas emprestadas...), creches e pré-escolas comunitárias nos bairros periféricos, como estratégia das mulheres para o ingresso no mercado de trabalho e propiciar às crianças um espaço para os cuidados básicos, sendo atendidas, em geral, as famílias com maiores dificuldades financeiras (SANTOS, 2013).

Em relação aos convênios celebrados entre os Ceics e as Prefeituras da BF, observa-se que as primeiras iniciativas aconteceram no final dos anos 1990, após a aprovação da CF/1988 (BRASIL, 1988) e antes ainda da aprovação de leis regulamentadoras que mais tarde passam a balizar essas conquistas. Contudo, mesmo nos municípios onde as instituições comunitárias possuem convênios, as dificuldades ainda são imensas, indo desde o baixo valor repassado, aos atrasos constantes, até as exigências cada vez mais difíceis de serem cumpridas. Nem sempre os convênios são de repasse financeiro, em alguns se refere à cessão de profissionais, à cessão de materiais de insumo e à capacitação.

Para efeito deste trabalho, consideramos que, tanto nos municípios do ERJ quanto em outros municípios do Brasil, “a política de parceria vem subjacente a um movimento social comunitário por recursos para instituições de Educação Infantil anteriormente financiadas pela assistência social." (SUSIN; PERONI, 2011, p. 186). As autoras trazem para o debate a questão do financiamento das políticas sociais, em especial aqui, a EI. Para elas, “[...] ao mesmo tempo em que 
a legislação passa a considerar a Educação Infantil do zero aos cinco anos como parte da Educação

Básica, e não mais como assistência, não houve alocação de recursos específicos para esta etapa da educação.” (SUSIN; PERONI, 2011, p. 186). Assim, os convênios dos Ceics com as Prefeituras são um importante apoio para a continuidade do funcionamento das iniciativas comunitárias e passam a ser central na luta do movimento organizado a partir do final dos anos 1990 e início dos anos 2000.

Ressaltamos que para firmar os convênios existe a possibilidade de utilizar os recursos do Fundeb, que são transferidos para os Estados, Distrito Federal e Municípios e só então o Poder Executivo competente repassa [ou não] os recursos às instituições comunitárias, confessionais ou filantrópicas conveniadas com o Poder Público.

\section{$O$ contexto da investigação}

De acordo com o $\mathrm{IBGE}^{18}$, o Brasil é dividido em Unidades da Federação (UF), Mesorregiões, Microrregiões e Municípios, com o ERJ ${ }^{19}$ possuindo, atualmente, 92 municípios, 6 mesorregiões e 18 microrregiões $^{20}$, com a terceira maior população do Brasil (17.159.960

18 IBGE; Centro de Referência em Nomes Geográficos; Referência e Identidade. Disponível em: $<$ http://www.ngb.ibge.gov.br/Default.aspx?pagina=divisao>. Acesso em: 25/jan./2016.

19 O ERJ foi "descoberto" no dia $1^{\circ}$. de janeiro de 1502 , quando navegadores portugueses avistaram a Baía de Guanabara e, acreditando que se tratava da foz de um grande rio, deram-lhe o nome de Rio de Janeiro, sendo uma das 27 Unidades da Federação (26 estados e 1 Distrito Federal) (BRASIL, 2020). Fruto da fusão com o antigo estado da Guanabara em 1975, o ERJ tem como capital a cidade homônima, a segunda cidade mais populosa do Brasil e principal centro cultural do país.

${ }^{20}$ i) Mesorregião Metropolitana do Rio de Janeiro: i.1) Microrregião do Rio de Janeiro: Rio de Janeiro, Belford Roxo, Duque de Caxias, Guapimirim, Itaboraí, Japeri, Magé, Maricá, Mesquita, Nilópolis, Niterói, Nova Iguaçu, Queimados, São Gonçalo, São João de Meriti, Tanguá. i.2) Microrregião de Itaguaí: Itaguaí, Mangaratiba, Seropédica.i.3) Microrregião Serrrana: Petrópolis, São José do Vale do Rio Preto, Teresópolis. i.4) Microrregião de Vassouras: Engenheiro Paulo de Frontin, Mendes, Miguel Pereira, Paracambi, Paty do Alferes, Vassouras. i.5) Microrregião de Macacu-Caceribu: Cachoeiras de Macacu, Rio Bonito. ii) Mesorregião do Noroeste Fluminense: ii.1) Microrregião de Itaperuna: Bom Jesus do Itabapoana, Italva, Itaperuna, Laje do Muriaé, Natividade, Porciúncula, Varre-Sai. ii.2) Microrregião de Santo Antonio de Pádua: Aperibé, Cambuci, Itaocara, Miracema, Santo Antônio de Pádua, São José de Ubá. iii) Mesorregião do Norte Fluminense: iii.1) Microrregião de Campos dos Goytacases: Campos dos Goytacazes, Cardoso Moreira, São Fidélis, São Francisco de Itabapoana, São João da Barra. III.2) Microrregião de Macaé: Carapebus, Conceição de Macabu, Macaé, Quissamã. iv) Mesorregião do Centro Fluminense: iv.1) Microrregião de Nova Friburgo: Bom Jardim, Duas Barras, Nova Friburgo, Sumidouro. iv.2) Microrregião de Santa Maria Madalena: Santa Maria Madalena, São Sebastião do Alto, Trajano de Moraes. iv.3) Microrregião de Cantagalo-Cordeiro: Cantagalo, Carmo, Cordeiro, Macuco. iv.4) Microrregião de Três Rios: Areal, Comendador Levy Gasparian, Paraíba do Sul, Sapucaia, Três Rios. v) Mesorregião das Baixadas: v.1) Microrregião dos Lagos: Araruama, Armação dos Búzios, Arraial do Cabo, Cabo Frio, Iguaba Grande, São Pedro da Aldeia, Saquarema. v.2) Microrregião da Bacia de São João: Casimiro de Abreu, Rio das Ostras, Silva Jardim. vi)

RBPPD/BRJPD| Vol. 2 | n. 3 |p. 55-85, 2020. 
habitantes), sendo superado apenas por São Paulo (45.538.936 habitantes) e Minas Gerais (21.040.662 habitantes), conforme estimativa do IBGE para o ano de 2018 (BRASIL, 2018). De acordo com o Censo de 2010 (BRASIL, 2010), observamos que a maior parte da população do estado encontra-se na faixa etária de 40 a 59 anos (25,5\%), seguida da faixa etária de 25 a 39 anos $(24,2 \%)$ e 15 a 24 anos (16,1\%). A faixa etária de 0 a 5 anos representa a menor percentagem (7,5\%), o que pode indicar que a população do estado está passando por um processo de envelhecimento.

A BF não é uma região oficial do ERJ, nem pela divisão territorial por Regiões de Governo $^{21}$, nem pela divisão político-administrativa proposta pelo IBGE, apesar de até recentemente possuir espaço na estrutura da Secretaria de Governo do ERJ ${ }^{22}$, como Subsecretaria de Estado da Baixada. A região faz parte da mesorregião Metropolitana do Rio de Janeiro, sendo composta por 13 municípios (Belford Roxo, Duque de Caxias, Guapimirim, Itaguaí, Japeri, Magé, Mesquita, Nilópolis, Nova Iguaçu, Paracambi, Queimados, São João de Meriti e Seropédica).

De forma resumida, podemos dizer que a BF, em sua formação histórica, passou por três grandes momentos de transformação econômica. No início do século XVII a ocupação do território se dava com a introdução da lavoura canavieira. Entre os séculos XVIII e XIX a preponderância mudou da cana de açúcar para a produção do café. No século XX a produção de laranja passa ser o cultivo com maior incidência nas terras da região (SANTOS, 1997; PORTO, 2001). Acrescentamos, ainda, um quarto momento, a transformação das chácaras de laranjais em loteamentos, após o declínio desse cultivo, em especial, a partir da Segunda Grande Guerra Mundial (SANTOS, 1997). A partir do final dos anos 1970, a BF é reconhecida pela pobreza da população e com a fama de ser uma das regiões mais violentas do ERJ, sendo, na atualidade, uma região com quase $23 \%$ da

Mesorregião do Sul Fluminense: vi.1) Microrregião do Vale do Paraíba Fluminense: Barra Mansa, Itatiaia, Pinheiral, Piraí, Porto Real, Quatis, Resende, Rio Claro, Volta Redonda. vi.2) Microrregião de Barra do Piraí: Barra do Piraí, Rio das Flores, Valença. vi.3) Microrregião da Baía da Ilha Grande: Angra dos Reis, Paraty.

${ }^{21}$ Organizada pela Ceperj - Fundação Centro Estadual de Estatísticas, Pesquisas e Formação de Servidores Públicos do Rio de Janeiro. Disponível em: $<$ http://www.ceperj.rj.gov.br/ceep/info_territorios/divis_politico_administrativo.html>. Acesso em: 28/mar./2018.

${ }^{22}$ Cf.: <http://www.rj.gov.br/web/segov/exibeconteudo?article-id=141028>. Acesso em: 16/jun./2013. 
população total do estado, de acordo com o Censo IBGE de 2010 (BRASIL, 2010), se constituindo ainda em uma área de grande concentração de pobreza, com situação dramática em todas as áreas: saúde, educação, cultura etc. Considerando a faixa etária de 0 a 5 anos, temos as maiores percentagens nos municípios de Japeri, Queimados, Guapimirim, Itaguaí, Belford Roxo e Magé, todos acima de $8,5 \%$ da população total. Abaixo de 7\%, encontramos apenas o município de Paracambi. A maior parte das populações encontra-se na faixa etária de 25 a 39 anos e de 40 a 59 anos, em torno de $25 \%$ em todos os municípios.

Em relação à EI na $\mathrm{BF}$, trazemos a sua origem ligada à luta pelo atendimento das crianças por influência do movimento feminista, com forte pressão do movimento comunitário, com a inclusão do tema da creche e da pré-escola na agenda política dos governantes da região, culminando, inclusive, com convênios do MEC com instituições comunitárias. Como já visto, além do MEC, outros convênios com as instituições comunitárias foram realizados pelos órgãos públicos, tanto federais, como estaduais. Muitas dessas iniciativas comunitárias tinham o apoio - e até o incentivo - de órgãos governamentais, como convênios, nos anos 1970, com a LBA, como, por exemplo, o Projeto Casulo (1974). Também a Feem passou, a partir do ano de 1979, a contratar serviços de entidades particulares para firmar convênios (SANTOS, 2013).

Assim, trazemos, nos pressupostos de Santos (2018), que o "território" importa quando pensamos na implementação de políticas públicas, pois, faz toda a diferença o lugar onde a pessoa mora, seja do município em relação à Capital, por exemplo, seja dentro do próprio município, que possui um perfil variado, que comporta uma "elite municipal" nas áreas centrais e, para aqueles expulsos destes espaços, tanto do próprio município como proveniente de outros Centros, resta morar nos loteamentos, muitas vezes clandestinos e/ou irregulares, da periferia urbana, marcados pela escassez de serviços urbanos e equipamentos de uso coletivo. 
Para fechar este item incorporamos os dados de atendimento na creche e na pré-escola no Brasil, no ERJ e na BF, tendo como base a compilação de dados primários do Censo Escolar do MEC/Inep (SANTOS, 2018), conforme estabelecido no gráfico abaixo.

Gráfico 01 - Atendimento em Creche e Pré-Escola no Brasil, no estado do Rio de Janeiro e na Baixada Fluminense, nos anos de 1996, 2006, 2016 e 2018.

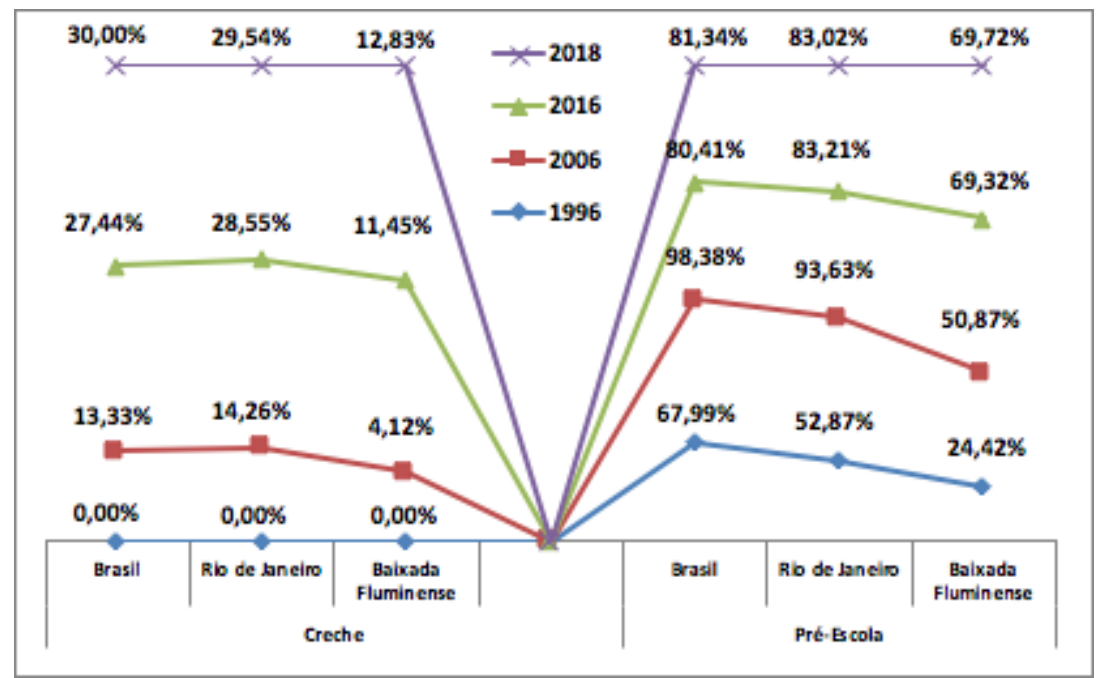

Fonte: Tabulação própria com base: IBGE/Sidra, Contagem da População, 1996. IBGE/DPE/Copis, para a população total, 2006, 2016, 2018. Para a faixa em 2006, 2016, 2018: estimativa com base nas percentagens do Censo Demográfico, IBGE, 2010. MEC/Inep, Censo Escolar. Número de Matrículas na Educação Infantil por Dependência Administrativa e Municípios do Estado do RJ e Brasil, 1996, 2006, 2016 e 2018.

Uma das dificuldades encontradas foi a obtenção de dados dos Censos Educacionais sobre as creches, que, de acordo com Nunes, Corsino e Kramer (2011), só começaram a ser produzidas a partir do ano de 2001, prejudicando a ideia original de mapear o avanço do atendimento na creche a partir de 1996. Entretanto, cabe explicitar que o atendimento em creche não era nulo, como parece ser. Na verdade, as crianças desta faixa etária eram atendidas em creches no âmbito da Assistência Social, não sendo contabilizadas no Censo Escolar. Comparando os dados da creche, temos, em 2006, um atendimento das crianças de 0 a 3 anos de 13,33\% no Brasil, uma percentagem um pouco maior no ERJ (14,26\%), com a BF com um atendimento irrisório de menos de 5,00\%. Em 2018, o 
Brasil e o ERJ apresentam um aumento passando a atender uma percentagem de 30,00\% e 29,54\%, respectivamente, com a $\mathrm{BF}$ avançando para $12,83 \%$.

Considerando a pré-escola, os dados já são mais substanciais desde o ano de 1996, aparecendo uma percentagem de atendimento de crianças de 4 e 5 anos na ordem de $67,99 \%$ no Brasil e 52,87\% no ERJ, porém com a BF também apresentando o pior resultado, com apenas 24,42\%. Em 2006, o Brasil passa a atender 98,38\%, enquanto o ERJ chega a 93,63\%, supondo o atendimento de crianças de 4 e 5 anos. Enquanto isso, a BF atende pouco mais de 50,00\%. Em 2018, identificamos queda no atendimento tanto para o Brasil, que atinge $81,34 \%$, como para o ERJ, que passa atender 83,02\%. Enquanto isso, a BF apresenta-se com menos de 70,00\% do atendimento.

$\mathrm{O}$ baixo atendimento da $\mathrm{BF}$ em relação à EI é mais um dos indicadores para uma região já repleta de índices negativos em várias áreas, confirmando o anunciado por Campos e Cruz (2006, p. 13), baseado em estudos de Kappel, Kramer e Carvalho (2001) ${ }^{23}$, que "quanto menor a renda da população, menor o percentual de crianças matriculadas em creches e pré-escolas, o que revela uma sonegação desse direito justamente àquelas famílias e crianças mais necessitadas desse atendimento." Contudo, ressaltamos que a legislação construída no Brasil ao longo do tempo adverte que os municípios devem ofertar vagas suficientes para atender à demanda, pois temos a criança considerada como sujeito de direitos, independentemente de qualquer circunstância como gênero, raça/etnia, religião, classe social, local de moradia ou de condição econômica. Assim, é importante identificar como o acesso das crianças à EI foi - ou está sendo - construído.

\section{A Política de conveniamento com instituições de fins não-econômicos}

\footnotetext{
${ }^{23}$ KAPPEL, Maria Dolores B.; KRAMER, Sonia e CARVALHO, Maria Cristina. Perfil das crianças de O a 6 anos que freqüentam creches, pré-escolas e escolas: uma análise dos 84 resultados da Pesquisa sobre Padrões de Vida/IBGE. Revista Brasileira de Educação, n. 16, jan./fev./mar./abr. 2001, p. 35-47.
} 
Temos visto, a partir de vários estudos publicados, a divulgação de resultados que apontam que a ampliação do acesso à EI no Brasil, especialmente, após a obrigatoriedade do segmento da pré-escola, tem se dado a partir dos convênios, notadamente com instituições sem fins lucrativos (SUSIN; PERONI, 2011; FLORES; SUSIN, 2013; PIRES, 2013; PERONI, 2013; TRIPODI, 2016), o que trouxe como tema central desta investigação buscar desvendar se tais resultados encontram eco na realidade do ERJ e da BF. Assim, torna-se oportuna a investigação da parceria entre unidades de EI privadas e órgãos públicos, em especial, com as instituições de fins não-econômicos, que era realizada no âmbito da Assistência Social a partir do final dos anos 1970 (SANTOS, 2013). Com a aprovação da LDB (BRASIL, 1996), as instituições de fins não-econômicos foram transferidas para os Sistemas de Ensino, contudo, levando um longo tempo, somente sendo consolidada a transferência com a possibilidade de financiamento a partir da aprovação do Fundeb, em 2006.

Dada à questão recorrente de que os municípios utilizam parcerias com instituições de fins não-econômicos para a ampliação de vagas na EI, em especial, na pré-escola, compilamos os dados do $\mathrm{FNDE}^{24}$ relacionados às instituições conveniadas consideradas para os recursos do Fundeb dos anos 2008 a 2019 para chegar ao número das matrículas conveniadas. Para a obtenção dos dados realizamos um levantamento com informações detalhadas, seja pelos diferentes territórios do ERJ (mesorregiões, microrregiões e municípios), bem como pelas etapas da EI (creche e pré-escola) e também pelos diferentes tipos de atendimento (parcial, integral e Educação Especial). É importante ressaltar que "ser considerada para os recursos do Fundeb" não significa que houve parceria de fato, pois muitos municípios desconsideram essa informação e não estabelecem convênios de repasse de per capita, quando muito utilizam outras formas, tais como, cessão de materiais e/ou recursos humanos. De qualquer forma, as informações disponibilizadas pelo FNDE são muito importantes para traçarmos um perfil dos municípios que adotam ou poderiam adotar o expediente de

${ }^{24}$ O FNDE (ver Nota 4), disponibiliza anualmente uma planilha com todos os estados, listando as instituições que possuem possibilidade de acessar recursos do Fundeb, por municípios, com base no Censo Escolar do ano anterior. 
estabelecer convênios com repasse de recursos para as instituições de fins não-econômicos (comunitárias, confessionais e filantrópicas).

Ademais, achamos oportuno trazer as informações sobre esse quesito, pois tal modalidade de oferta educacional persiste no atual PNE, consolidado na estratégia 1.7, com o seguinte texto: “articular a oferta de matrículas gratuitas em creches certificadas como entidades beneficentes de assistência social na área de educação ${ }^{25}$ com a expansão da oferta na rede escolar pública." (BRASIL, 2014a). É importante ressaltar que a estratégia estimula a oferta em creches por meio da concessão de certificado, o que gerou muita pressão no processo de tramitação do PNE no Congresso Nacional no sentido de sua exclusão, em defesa do princípio da verba pública para educação pública, porém, a estratégia foi mantida na Lei aprovada.

Observamos que, dos 92 municípios do ERJ, 70 poderiam estabelecer convênios em pelo menos 1 ano no período estudado (2008-2019). Dos 13 municípios da BF, em apenas 2 não estavam previstos convênios em pelo menos 1 dos anos estudados (Guapimirim e Japeri). Contudo, os convênios não acontecem com regularidade, podendo ocorrer em uma determinada gestão e desaparecer na seguinte. Por exemplo, de acordo com os dados consolidados nesta investigação, em 2008, o ERJ tinha 36 municípios realizando convênios, aumentando para 49, em 2012, porém retrocedendo em 2019 para 34. O mesmo fenômeno ocorreu na BF, partindo de 2, em 2008, passando para 9, em 2012, e diminuindo para 6, em 2019.

De acordo com o Anexo 1, temos, em 2008, considerando o total de matrículas previstas para convênios em creche (19.964), que a Mesorregião Metropolitana do Rio de Janeiro - MMRJ responde por 90,2\% das matrículas (18.006), com preponderância para o município do Rio de Janeiro, que sozinho chega à $72,4 \%$ do quantitativo estadual (14.459). Considerando as matrículas

\footnotetext{
${ }^{25}$ O Cebas - Educação foi uma conquista conseguida por meio da Lei no ${ }^{\circ}$ 12.101/2009 (BRASIL, 2009b), que permite a concessão do Cebas pelo MEC e uma nova possibilidade para o atendimento de crianças pelas instituições comunitárias, confessionais ou filantrópicas sem fins lucrativos.
} 
previstas para conveniamento em creche na BF para o mesmo ano identificamos uma percentagem de $6,8 \%$ das vagas observadas no estado (1.359).

Observando o ano de 2012, onde foi visto um crescimento acentuado nas matrículas previstas para convênios em creche (26.204), a MMRJ responde por 90,7\% das vagas (23.759), com o município do Rio de Janeiro sendo responsável por 67,9\% das matrículas previstas. No ano em questão, a BF encontra-se com 8,5\% das matrículas previstas para o estado (2.231).

Seguindo o mesmo raciocínio, aportamos no ano de 2019 com um total de 24.009 matrículas em creche, sendo que 90,2\% delas encontram-se na MMRJ (21.657), com preponderância do município do Rio de Janeiro, com 65,1\% (15.632). No mesmo ano, a BF responde por 9,4\% das matrículas previstas para conveniamento em creche (2.259).

É importante mencionar que os municípios priorizavam o estabelecimento de convênios com as instituições que atendiam à creche, pois, o horizonte de matrículas da pré-escola por conveniamento encerraria em 2011, 4 anos após a aprovação do Fundeb. Por isso, a parceria para matrículas em creches era mais seguro ao Poder Público, pois, seriam garantidos os recursos necessários para cobrir os custos dessa modalidade de parceria até o final da vigência do Fundo. Em relação ao atendimento em pré-escola, notamos que os municípios não priorizavam o estabelecimento de convênios para este segmento, porém, passaram a levar em conta após a prorrogação da contabilização dessas matrículas, primeiramente, de 2012 a 2016, e, posteriormente, até a universalização da pré-escola.

Assim, também levando em conta o Anexo 1, em 2008, observa-se um baixo número de matrículas previstas para convênios em pré-escola no estado (880), sendo 39,7\% na RMRJ, sendo a maioria no município de Niterói, com $21,5 \%$ das matrículas (189). No ano mencionado, a BF contribui apenas com $0,7 \%$ das matrículas previstas em pré-escola (6), todas na Educação Especial.

Em 2012, com a garantia de recursos para a pré-escola conveniada, observamos um aumento nas matrículas no segmento, chegando a 11.425 vagas previstas, com 85,3\% na MMRJ (9.741), 
com a preponderância para o município do Rio de Janeiro, com 29,7\% das vagas (3.398). No ano em questão, a BF contribui com 17,0\% das matrículas previstas para conveniamento no estado (1.943).

Em 2019, o quantitativo de matrículas previstas na pré-escola conveniada apresentou queda em relação aos anos anteriores, com 7.997 vagas, sendo 93,2\% na MMRJ e a preponderância no município de Niterói, que atingiu 18,1\% das matrículas (1.445). No mesmo ano a BF também observou queda para 1.353 vagas previstas para convênio na pré-escola, $16,9 \%$ das matrículas do estado.

Quando desagregamos as informações do Anexo 1, observamos que a maior parte dos convênios relacionam-se à creche na modalidade integral, tais como, em 2008, onde temos 18.868, correspondendo a $94,5 \%$ do segmento ou 90,5\% do total de 20.844 matrículas previstas para convênio, seguida de Educação Especial (575) e parcial (521). No ano em questão, a pré-escola só possui convênio na Educação Especial, com 880 matrículas. O mesmo fenômeno ocorre na BF, com as matrículas se concentrando na creche integral (1.262 das 1.359 matrículas previstas para a creche), tendo apenas 6 matrículas em Educação Especial para a pré-escola. Até o ano de 2011, a tendência continua em aumento do atendimento por convênio em creche integral, tanto no ERJ (com preponderância na MMRJ), como na BF, com a previsão de conveniamento na pré-escola só para a Educação Especial.

Em 2012, mesmo com a garantia de aporte do Fundeb para a pré-escola, mantém-se a preponderância na creche. Vejamos, no ano em questão o ERJ possuía 24.132 vagas previstas para a creche integral $(92,1 \%$ do segmento e $64,1 \%$ do total). Contudo, a pré-escola passa a ser admitida para 11.425 matrículas, sendo 4.823 parciais, 6.422 integrais e 180 para Educação Especial, ocupando $30,4 \%$ do total de 37.629 matrículas conveniadas. No mesmo ano, a BF contribui com $17 \%$ das matrículas em pré-escola previstas para o estado (1.943), com a maioria na modalidade parcial (1.207), seguida da integral (731) e Educação Especial (5). 
No ano de 2019, o predomínio continua sendo do atendimento em creche integral $(22.618$ vagas previstas), seguidas da parcial (1.300) e Educação Especial (91), totalizando 24.009 matrículas, que significa $75,0 \%$ das vagas conveniadas. No ano mencionado, a BF responde por 9,4\% das matrículas previstas para creche conveniada (2.259), distribuída em parcial (815), integral (1.441) e Educação Especial (3).

Como já visto, as vagas da pré-escola foram diminuindo ao longo dos anos, chegando em 2019 com 7.997 matrículas previstas no estado $(25,0 \%$ das matrículas previstas para conveniamento), distribuídas em parcial (1.915), integral (5.249) e Educação Especial (833). A BF contribui no ano com $16,9 \%$ das matrículas previstas para o estado (1.353), divididas em parcial (800), integral (552) e Educação Especial (1).

O quadro abaixo resume o exposto no Anexo 1, trazendo o somatório de matrículas previstas para a creche e a pré-escola, nas diferentes modalidades (parcial, integral e Educação Especial) pelas Mesorregiões do ERJ e pela BF, nos anos de 2008 a 2019.

Tabela 01 - Matrículas por conveniamento total do estado do Rio de Janeiro, divididas por Mesorregiões e pela Baixada Fluminense, de 2008 a 2019.

\begin{tabular}{|c|c|c|c|c|c|c|c|c|c|c|c|c|}
\hline MESORREGIÄO & ANO 2008 & ANO 2009 & ANO 2010 & ANO 2011 & ANO 2012 & ANO 2013 & ANO 2014 & ANO 2015 & ANO 2016 & ANO 2017 & ANO 2018 & ANO 2019 \\
\hline Metropolitana do Rio de Janeiro & 18355 & 18327 & 20342 & 23357 & 33500 & 33488 & 31620 & 31481 & 31886 & 31088 & 30810 & 29110 \\
\hline do Noroeste Fluminense & 627 & 741 & 636 & 686 & 834 & 873 & 864 & 1148 & 1275 & 1135 & 1219 & 1285 \\
\hline Região Norte Fluminense & 509 & 320 & 269 & 156 & 469 & 251 & 210 & 197 & 210 & 189 & 171 & 66 \\
\hline do Centro Fluminense & 178 & 246 & 252 & 237 & 618 & 601 & 728 & 630 & 607 & 572 & 586 & 361 \\
\hline das Baixadas & 129 & 165 & 127 & 235 & 391 & 281 & 192 & 367 & 307 & 397 & 162 & 173 \\
\hline do Sul Fluminense & 1046 & 1220 & 1284 & 1527 & 1817 & 1780 & 1628 & 1735 & 1806 & 1823 & 1936 & 1011 \\
\hline Estado do Rio de Janeiro & 20844 & 21019 & 22910 & 26198 & 37629 & 37274 & 35242 & 35558 & 36091 & 35204 & 34884 & 32006 \\
\hline Baixada Fluminense & 1365 & 1271 & 1830 & 2662 & 4174 & 3915 & 3315 & 3414 & 3162 & 3295 & 3399 & 3612 \\
\hline
\end{tabular}

Fonte: Tabulação Própria, com base: MEC/Fundo Nacional de Desenvolvimento da Educação - FNDE/Fundo de Manutenção e Desenvolvimento da Educação Básica e de Valorização dos Profissionais da Educação - Fundeb, 2008 a 2019.

Considerando o período estudado, observamos um aumento de 53,6\% no número total de matrículas previstas para convênios no ERJ, saindo de 20.844 em 2008 para 32.006 vagas em 2019. Notamos também um aumento no número de matrículas previstas para convênio na BF na ordem de 164,6\%, saindo de 1.365 matrículas previstas em 2008 para 3.612 em 2019. Em relação aos 
segmentos da EI, houve um aumento percentual em ambos em relação ao número de matrícula por convênios, com a creche aumentando 20,3\% no período de 2008 a 2019, saindo de 19.964 para 24.009 matrículas e com a pré-escola com aumento percentual de $808,8 \%$, partindo de 880 para 7.997 matrículas. Na BF, a creche experimenta um aumento de 66,2\%, indo de 1.359 matrículas previstas em 2008 para 2.259 em 2019, com a pré-escola crescendo em $22.450,0 \%$, saindo de 6 vagas previstas para 1.353 .

Contudo, as análises têm que ser feitas com muita parcimônia, levando em conta todo o universo das matrículas da etapa e ponderando que muitos desses convênios foram migrados das Secretarias de Assistência Social para a Educação ao longo do tempo, em especial, após a aprovação do Fundeb, que incluiu essa possibilidade de financiamento. Ou seja, apesar do aumento percentual, em termos numéricos, comparando com o universo das crianças atendidas, não representa um atendimento significativo, pois, pelos dados apurados nesta investigação, concluímos que esta não é uma estratégia para a expansão de vagas na EI, nem no estado e nem na região estudada, já que representa uma pequena percentagem comparando com o atendimento municipal e particular. A título de exemplo, somando-se as matrículas de creches e pré-escolas em 2018 (Censo Escolar), temos 619.058 matrículas no ERJ. Portanto, com a percentagem de matrículas para conveniamento neste ano representando $5,6 \%$ do total (34.884), caso todas as matrículas consideradas pelo FNDE fossem realmente efetivadas pelos municípios. Utilizando o mesmo raciocínio para a BF, as matrículas totais previstas para convênio em 2018 (3.399) contribuem apenas com 3,2\% das matrículas totais da região (105.389).

Assim, apesar do ERJ e da BF possuírem um movimento comunitário atuante, com forte participação desde o final dos anos 1970, conseguindo convênios ainda no escopo da Assistência Social, avaliamos que não logrou êxito na passagem para a Educação (SANTOS, 2013). Pois, levou-se um longo tempo para essas matrículas serem consideradas, ainda assim, de forma instável, tanto no número de municípios como no número de matrículas. Observamos, desta forma, que o 
ERJ e a BF não privilegiam as matrículas conveniadas para a ampliação do acesso na EI, o que mostra que, mesmo apresentando ainda baixo atendimento, a expansão ocorre a partir de unidades municipais e particulares. Quer dizer, com as informações acima é possível inferir que, apesar do aumento percentual, que, como mencionado, obteve um aumento entre 2008 e 2019 de 53,6\% e 164,6\%, para o ERJ e BF, respectivamente, ainda temos uma preponderância de matrículas na rede municipal e particular em sentido estrito (com fins lucrativos), com as matrículas conveniadas contribuindo apenas com uma pequena percentagem (5,6\% para o ERJ e 3,2\% para a BF, em 2018), não sendo, portanto, utilizada em larga escala.

\section{Algumas considerações}

Identificamos a política pública de EI como sendo universalista ou redistributiva (prevista para atender a todas as crianças), mas, também, convivendo com vários tipos de políticas, tais como, meritocráticas-corporativas (pela participação da iniciativa privada na oferta dos serviços); residualistas ou compensatórias ou distributivas (intenção de atender a grupos sociais específicos na falta de vagas para todos); institucionais (aprovação de legislações diversas em conselhos); e regulatórias (aprovação de leis dos parlamentos) (SANTOS, 2018). Contudo, com os dados mencionados neste artigo, concluímos que ainda é necessário um grande esforço na busca do atendimento na EI.

Como é comum relacionar a ampliação de vagas com a oferta de matrículas via parceria com instituições de fins não-econômicos, o presente artigo teve como objetivo averiguar essa variável no ERJ e na BF, a partir dos dados disponibilizados pelo FNDE, de 2008 a 2019, relacionado às instituições consideradas para a distribuição dos recursos do Fundeb. Assim, com os dados consolidados, tanto para a BF como para o ERJ de forma geral, estabelecemos com meridiana clareza que, a despeito das impressões gerais que sempre colocam o ERJ como utilizando convênios com as instituições de fins não-econômicos para a ampliação do atendimento na EI, isso não é uma 
verdade absoluta, retornando ao título deste artigo, onde tomamos por empréstimo do poeta Cazuza a expressão "Suas ideias não correspondem aos fatos", pois, como aqui foi demonstrado, a ampliação vem se dando com o aumento do atendimento municipal, ainda que conte com suporte da rede privada, em especial, das unidades particulares em sentido estrito, ou seja, com fins lucrativos. Ademais, a maioria das matrículas conveniadas acontece na creche e não no segmento obrigatório (pré-escola). Na verdade, temos no ERJ um movimento comunitário forte e atuante, com participação efetiva nos rumos das lutas políticas da EI do estado e, até mesmo, nacional, sem, contudo, transformar essa presença em ocupação de vagas de forma significativa, restando, como deve ser, a expansão via ampliação das unidades municipais, sem deixar de contar com o aporte das unidades particulares e, em menor medida, das instituições de fins não-econômicos.

Como aventa este artigo, o direito à EI no Brasil já está consagrado na legislação, contudo, como também foi apontado, ainda não está em plena vigência, apesar dos esforços empreendidos e das vitórias conquistadas ao longo do tempo, em especial, pela influência da legislação, que coloca o atendimento na etapa como um direito das crianças. A política de EI foi gestada há muito tempo, com claros objetivos conquistados, atualmente sendo considerada a primeira etapa da EB, com obrigação legal de atendimento pelo Estado e como direito subjetivo para as crianças de 4 e 5 anos, a partir da EC no. 59/2009 (BRASIL, 2009a), referendada pela Lei no . 12.796/2013 (BRASIL, 2013). O atendimento na EI, em especial na região estudada, aumentou seu atendimento ao longo do tempo, mas ainda está aquém do atendimento desejado.

Valarelli et al. (2011, p. 80) acentuam que "apesar de termos uma Constituição avançada, que afirma o direito à educação, e de termos declarações internacionais que reafirmam esse direito, o contingente de pessoas sem acesso à escola e sem acesso à qualidade de ensino é alarmante.” $\mathrm{O}$ mesmo acontece em relação à EI, onde, por exemplo, em 2018, apuramos que o Brasil atende 30\% das crianças de 0 a 3 anos em creche, enquanto o ERJ se aproxima desse mesmo percentual. A BF, região focal deste artigo, atende no mesmo ano perto de $13 \%$ da faixa etária em questão. Apesar dos 
dados serem um pouco melhores, as diferenças também são acentuadas na pré-escola, onde, em 2018, o Brasil atende cerca de $81 \%$ das crianças de 4 e 5 anos e o estado perto de $83 \%$. Também aqui, a BF continua com resultados aquém dos encontrados anteriormente, atendendo menos de $70 \%$ da clientela.

Desta forma, apesar do avanço tanto da legislação quanto do percentual de crianças atendidas, nem todas as crianças na idade da EI estão atendidas, o que prejudica sobremaneira as crianças dos estratos sociais mais desfavorecidos, que são os últimos a acessar a política pública, que, em geral, só acontece com o advento da universalização. Assim, muitas crianças estão privadas do direito humano do acesso à EI. Em outros níveis de ensino, existe a possibilidade de acessá-los em outros momentos, na forma regular e supletiva, contudo, na EI este tempo não volta mais; perderam essas experiências, elas estão perdidas para sempre. Isto posto, concordamos com Valarelli et al. (2011, p. 80), que "não é possível pensarmos um país socialmente justo e economicamente desenvolvido enquanto houver a exclusão de contingentes inteiros de crianças, jovens e adultos dos processos de aprendizagem e da reflexão que a escola propicia.”

Consideramos que os dados arrolados no presente estudo devem ser divulgados, publicizados como ferramenta de ação política, que pode trazer uma contribuição aos processos de monitoramento da política pública de EI, por diferentes fóruns e movimentos; contudo, sem esgotar a complexidade do tema, que demanda novos estudos e pesquisas com o fito de aprofundar o debate sobre o acesso à EI, com qualidade social, para todas as crianças.

\section{Referências}

BALL, Stephen. Entrevista com Stephen J. Ball: um diálogo sobre justiça social, pesquisa e política educacional. Entrevista concedida a Jefferson Mainardes e Maria Inês Marcondes. Educação e Sociedade, v. 30, n. 106, jan./abr. 2009. Disponível em: $<$ https://www.scielo.br/pdf/es/v30n106/v30n106a15.pdf $>$. Acesso em: 10 jul. 2012.

BRASIL. CONGRESSO NACIONAL. Constituição da República Federativa do Brasil de 1988. Disponível em: <http://www.planalto.gov.br/ccivil_03/Constituicao/Constitui\%C3\%A7ao.htm>. Acesso em: 5/mar./2012. 1998. 
. CONGRESSO NACIONAL. Emenda Constitucional n ${ }^{0} .53$, de 19 de dezembro de 2006.

Dá nova redação aos arts. $7^{\circ}, 23,30,206,208,211$ e 212 da Constituição Federal e ao art. 60 do Ato das Disposições Constitucionais Transitórias. Disponível em:

$<$ http://www.planalto.gov.br/ccivil_03/constituicao/Emendas/Emc/emc53.htm>. Acesso em: 28/mar./2015. 2006a.

. CONGRESSO NACIONAL. Emenda Constitucional n ${ }^{\circ}$. 59, de 11 de novembro de 2009. Acrescenta $\S 3^{\circ}$. ao art. 76 do Ato das Disposições Constitucionais Transitórias para reduzir, anualmente, a partir do exercício de 2009, o percentual da Desvinculação das Receitas da União incidente sobre os recursos destinados à manutenção e desenvolvimento do ensino de que trata o art. 212 da Constituição Federal, dá nova redação aos incisos I e VII do art. 208, de forma a prever a obrigatoriedade do ensino de quatro a dezessete anos e ampliar a abrangência dos programas suplementares para todas as etapas da educação básica, e dá nova redação ao $\S 4^{\circ}$. do art. 211 e ao $\S$ $3^{\circ}$. do art. 212 e ao caput do art. 214, com a inserção neste dispositivo de inciso VI. Disponível em: $<$ http://www.planalto.gov.br/ccivil_03/constituicao/emendas/emc/emc59.htm>. Acesso em: 5/mar./2012. 2009a.

. CONGRESSO NACIONAL. Lei $\mathbf{n}^{\mathbf{0}}$. 5.537, de 21 de novembro de 1968. Cria o Instituto Nacional de Desenvolvimento da Educação e Pesquisa (Indep) [transformado em FNDE, em 1969], e dá outras providências. Disponível em: <http://www.planalto.gov.br/ccivil_03/LEIS/L5537.htm>. Acesso em 5/set./2020. 1968.

. CONGRESSO NACIONAL. Lei $\mathbf{n}^{\mathbf{0}}$. 8.069, de 13 de julho de 1990. Dispõe sobre o Estatuto da Criança e do Adolescente e dá outras providências. Disponível em: $<$ http://www.planalto.gov.br/ccivil_03/leis/18069.htm>. Acesso em: 5/set./2020. 1990.

. CONGRESSO NACIONAL. Lei nº 9.394, de 20 de dezembro de 1996. Estabelece as diretrizes e bases da educação nacional. Disponível em:

$<$ http://www.planalto.gov.br/ccivil_03/leis/L9394.htm>. Acesso em: 5/mar./2012. 1996.

. CONGRESSO NACIONAL. Lei no $\mathbf{0}$ 10.172, de 9 de janeiro de 2001. Aprova o Plano Nacional de Educação e dá outras providências. 2001. Disponível em $<$ http://www.planalto.gov.br/ccivil_03/leis/leis_2001/110172.htm>. Acesso em: 23/mar./2012. 2001.

. CONGRESSO NACIONAL. Lei no . 11.494, de 20 de junho de 2007. Regulamenta o Fundo de Manutenção e Desenvolvimento da Educação Básica e de Valorização dos Profissionais da Educação - Fundeb, de que trata o art. 60 do Ato das Disposições Constitucionais Transitórias; altera a Lei $\mathrm{n}^{\circ} 10.195$, de 14 de fevereiro de 2001; revoga dispositivos das Leis $\mathrm{n}^{\text {os }} .9 .424$, de 24 de dezembro de 1996, 10.880, de 9 de junho de 2004, e 10.845, de 5 de março de 2004; e dá outras providências. Disponível em:

$<$ http://www.planalto.gov.br/ccivil_03/_ato2007-2010/2007/Lei/L11494.htm>. Acesso em: 5/mar./2012. 2007a.

. CONGRESSO NACIONAL. Lei $\mathbf{n}^{\mathbf{0}} \mathbf{. 1 2 . 1 0 1}$, de 27 de novembro de 2009. Dispõe sobre a certificação das entidades beneficentes de assistência social; regula os procedimentos de isenção de contribuições para a seguridade social; altera a Lei no 8.742, de 7 de dezembro de 1993; revoga dispositivos das Leis nos 8.212, de 24 de julho de 1991, 9.429, de 26 de dezembro de 1996, 9.732, de 11 de dezembro de 1998, 10.684, de 30 de maio de 2003, e da Medida Provisória no 2.187-13, de

RBPPD/BRJPD| Vol. 2 | n. 3 |p. 55-85, 2020. 
24 de agosto de 2001; e dá outras providências. Disponível em: < http://www.planalto.gov.br/ccivil_03/_Ato2007-2010/2009/Lei/L12101.htm>. Acesso em: 5/set./2020. 2009b.

. CONGRESSO NACIONAL. Lei $\mathbf{n}^{\mathbf{0}} \mathbf{1 2 . 7 9 6}$, de 04 de abril de 2013. Altera a Lei ${ }^{\circ}$. 9.394, de 20 de dezembro de 1996, que estabelece as diretrizes e bases da educação nacional, para dispor sobre a formação dos profissionais da educação e dar outras providências. Disponível em: $<\mathrm{http}: / /$ www.legisweb.com.br/legislacao/?legislacao=253025>. Acesso em: 5/mai./2013. 2013.

. CONGRESSO NACIONAL. Lei n⿳0. 13.005, de 25 de junho de 2014. Aprova o Plano Nacional de Educação - PNE e dá outras providências. Disponível em: $<$ http://www.planalto.gov.br/ccivil_03/_Ato2011-2014/2014/Lei/L13005.htm>. Acesso em: 1/fev./2015. 2014a.

. CONGRESSO NACIONAL. Lei $\mathbf{n}^{\mathbf{0}} \mathbf{\text { 13.019, de }} 31$ de julho de 2014. Estabelece o regime jurídico das parcerias entre a administração pública e as organizações da sociedade civil, em regime de mútua cooperação; e altera as Leis ${ }^{\text {os }} .8 .429$, de 2 de junho de 1992, e 9.790, de 23 de março de 1999. Disponível em: <http://www.planalto.gov.br/ccivil_03/_ato2011-2014/2014/lei/113019.htm>. Acesso em: 7/abr./2018. 2014b.

. CONGRESSO NACIONAL. Lei $\mathbf{n}^{\mathbf{0}}$. 13.348, de 10 de outubro de 2016. Altera as Leis $\mathrm{n}^{\text {os }}$. 12.722 , de 3 de outubro de 2012, e 11.494, de 20 de junho de 2007; e 10.195, de 14 de fevereiro de 2001; revoga dispositivos das Leis $n^{\text {os }}$. 9.424, de 24 de dezembro de 1996, 10.880, de 9 de junho de 2004, e 10.845, de 5 de março de 2004; e dá outras providências". Disponível em: $<$ http://www.planalto.gov.br/ccivil_03/_Ato2015-2018/2016/Lei/L13348.htm\#art2>. Acesso em: 8/jan./2017. 2016b.

. FUNDO NACIONAL DE DESENVOLVIMENTO DA EDUCAÇÃO. Instituições conveniadas e alunos considerados na distribuição de recursos do Fundeb. Brasília: FNDE, 2008 a 2019.

. INSTITUTO BRASILEIRO DE GEOGRAFIA E ESTATÍSTICA. Censo demográfico 2010. Disponível em: <https://censo2010.ibge.gov.br/>. Acesso em: 5/set./2020. 2010.

INSTITUTO BRASILEIRO DE GEOGRAFIA E ESTATÍSTICA. Estimativas populacionais 2018. Disponível em:

$<$ https://www.ibge.gov.br/estatisticas/sociais/populacao/9103-estimativas-de-populacao.html?edica $\mathrm{o}=22367 \& \mathrm{t}=$ resultados $>$. Acesso em: 5/set./2020. 2018.

. INSTITUTO NACIONAL DE ESTUDOS E PESQUISAS EDUCACIONAIS ANÍSIO TEIXEIRA. Sinopse estatística da educação básica 1996, 2006, 2016 e 2018. Brasília: Inep, 1997, 2007, 2017 e 2018. Disponível em:

$<$ http://portal.inep.gov.br/sinopses-estatisticas-da-educacao-basica $>$. Acesso em: 10/jun./2019.

MINISTÉRIO DA ECONOMIA. Conheça as unidades federativas brasileiras. Publicado em 10/abr./2018, atualizado em 26/mai./2020. 2020. Disponível em:

<WWW.gov.br/produtividade-e-comercio-exterior/pt.br/assuntos/competitividadeindustrial/renai/co nheca-as-unidades-federativas-brasileiras>. Acesso em: 4/set./2020. 2020.

RBPPD/BRJPD| Vol. 2 | n. 3 |p. 55-85, 2020. 
. MINISTÉRIO DA EDUCAÇÃO. Conferência Nacional de Educação: Documento Final. Brasília: MEC/Secretaria Executiva/Secretaria Executiva Adjunta, 2010.

PRESIDÊNCIA DA REPÚBLICA. Decreto-Lei no ${ }^{\circ}$. 872, de 15 de setembro de 1969. Complementa disposições da Lei número 5.537, de 21 de novembro de 1968, e dá outras providências. Disponível em:

$<$ http://www.planalto.gov.br/ccivil_03/Decreto-Lei/1965-1988/Del0872.htm>. Acesso em: 5/set./2020. 1969.

. PRESIDÊNCIA DA REPÚBLICA. Decreto n $\mathbf{n}^{\mathbf{0}} \mathbf{6 . 2 5 3}$, de 13 de novembro de 2007. Dispõe sobre o Fundo de Manutenção e Desenvolvimento da Educação Básica e de Valorização dos Profissionais da Educação - FUNDEB, regulamenta a Lei no ${ }^{\circ}$ 11.494, de 20 de junho de 2007, e dá outras providências. Disponível em:

$<$ http://www.planalto.gov.br/ccivil_03/_ato2007-2010/2007/Decreto/D6253.htm>. Acesso em: 5/mar./2012. $2007 \mathrm{~b}$.

CABRAL, Angela Varella. Estudo do "menor carente" na perspectiva da política da Fundação Nacional do Bem-Estar do Menor (Funabem). Dissertação de Mestrado. Rio de Janeiro: Fundação Getúlio Vargas/Instituto de Estudos Avançados em Educação/Departamento de Psicologia em Educação, 1982.

CAMPOS, Maria Malta; CRUZ, Silvia Helena Vieira (relatoras). Consulta sobre qualidade da educação infantil: o que pensam e querem os sujeitos deste direito. São Paulo: Cortez, 2006.

CIVILETTI, Maria Vitória Pardal. O cuidado às crianças pequenas no Brasil escravista. São Paulo, Caderno de Pesquisa, Fundação Carlos Chagas, n. 76, fevereiro 1991, p. 31-40 (texto 4).

DEMO, Pedro. Introdução à metodologia da ciência. 2. ed. São Paulo: Atlas, 1985.

FLORES, Maria Luiza Rodrigues; SUSIN, Maria Otília Kroeff. Expansão da educação infantil através da parceria público-privada: algumas questões para o debate (quantidade versus qualidade no âmbito do direito à educação). In: PERONI, Vera Maria Vidal (org.). Redefinições das fronteiras entre o público e o privado: implicações para a democratização da educação. Brasília: Liber Livro, 2013.

FREIRE, Adriani Pinheiro; SIMÕES, Marinêz (Coord.). Diagnóstico de creches e pré-escolas da Baixada Fluminense. Rio de Janeiro: Fundação Fé e Alegria do Brasil/Nucrep, 2001.

KRAMER, Sonia; NUNES, Maria Fernanda R.; CORSINO, Patrícia. Infância e crianças de 6 anos: desafios das transições na educação infantil e no ensino fundamental. Educação e Pesquisa, São Paulo, v. 37, n. 1, 220p. 69-85, jan./abr. 2011.

KUHLMANN JUNIOR, Moysés. Instituições pré-escolares assistencialistas no Brasil (1889-1922). São Paulo, Caderno de Pesquisa, Fundação Carlos Chagas, n. 78, agosto 1991.

LOSACCO, Silvia. A institucionalização de crianças e adolescentes ao longo da história. Portal Pró-Menino. 9/9/2011.

RBPPD/BRJPD| Vol. 2 | n. 3 |p. 55-85, 2020. 
NUNES, Maria Fernanda Rezende; CORSINO, Patrícia; DIDONET, Vital. Educação Infantil no Brasil: primeira etapa da educação básica. Brasília: Unesco, Ministério da Educação/Secretaria de Educação Básica, Fundação Orsa, 2011.

NUNES, Maria Fernanda; CORSINO, Patrícia; KRAMER, Sonia. Com os questionários nas mãos: um balanço da década. In: NUNES, Maria Fernanda; CORSINO, Patrícia; KRAMER, Sônia.

Educação Infantil e formação de profissionais no estado do Rio de Janeiro. Rio de Janeiro: Traço e Cultura, 2011.

PERONI, Vera Maria Vidal. A privatização do público: implicações para a democratização da educação. In: (org.). Redefinições das fronteiras entre o público e o privado: implicações para a democratização da educação. Brasília: Liber Livro, 2013.

PIRES, Daniela de Oliveira. O histórico da relação público-privada no Brasil: o enfoque jurídico. In: PERONI, Vera Maria Vidal (org.). Redefinições das fronteiras entre o público e o privado: implicações para a democratização da educação. Brasília: Liber Livro, 2013.

PORTO, Hélio Ricardo Leite. Saneamento e cidadania: trajetórias e efeitos das políticas públicas de saneamento na Baixada Fluminense. Dissertação de Mestrado. Rio de Janeiro: UFRJ/Ippur, 2001.

RIO DE JANEIRO. CONSELHO ESTADUAL DE EDUCAÇÃO. Deliberação CEE nº 231/1998. Fixa normas para autorização de funcionamento de instituições privadas de Educação Básica e dá outras providências. 1998.

. CONSELHO ESTADUAL DE EDUCAÇÃO. Deliberação CEE nº 244/1999. Modifica o $\overline{\text { Artigo }} 3^{\circ}$. e acrescenta dois Parágrafos ao Artigo $8^{\circ}$. da Deliberação no . 231/1998. 1999a.

. CONSELHO ESTADUAL DE EDUCAÇÃO. Deliberação CEE nº . 245/1999. Fixa normas para autorização de funcionamento de instituições privadas de Educação Infantil que assistem e educam crianças de 0 a 6 anos e onze meses. 1999b.

SANTOS, Edson Cordeiro dos. A periferia da periferia: estudo do (e para o) loteamento Parque Todos os Santos (Nova Iguaçu - RJ), sob uma perspectiva Interdisciplinar. Monografia Especialização. Rio de Janeiro: Departamento de Ciências Sociais do Instituto de Filosofia e Ciências Humanas da Universidade Estadual do Rio de Janeiro, Curso de Especialização em Sociologia Urbana, 1997.

. Iniciativas populares: o movimento comunitário e a educação infantil na Baixada Fluminense. Dissertação (Mestrado em Educação). Rio de Janeiro: Universidade Federal do Estado do Rio de Janeiro - Unirio/PPGEd, 2013.

LDB - Duas décadas de desafios para a pré-escola: uma análise do monitoramento do acesso na Cidade de Nova Iguaçu entre 1996 e 2016. Tese (Doutorado) - Universidade Federal do Estado do Rio de Janeiro, Programa de Pós-Graduação em Educação, 2018.

SANTOS, Hermílio. Sociedades complexas e políticas. In: (Org.). Debates pertinentes: para entender a sociedade contemporânea. Porto Alegre: EDIPUCRS, 2009. 
SAVIANI, Dermeval. História das ideias pedagógicas no Brasil. Campinas, SP: Autores Associados, 2007.

SUSIN, Maria Otília Kroeff; PERONI, Vera Maria Vidal. A parceria entre o poder público municipal e as creches comunitárias: a educação infantil em Porto Alegre. In: Revista Brasileira de Política e Administração da Educação - RBPAE, v. 27, n. 2, mai./ago. 2011, p. 185-201.

TRIPODI, Zara Figueiredo. Educação infantil: da diversidade de oferta aos novos locais de governança. In: Educação, v. 39, n. 3, p. 383-392, Porto Alegre, set.-dez. 2016.

VALARELLI, Leandro et al. Mapeamento de experiências de monitoramento de políticas públicas pela sociedade civil no Brasil. In: ROMANO, Jorge; HERINGER, Rosana (Org.). A política vivida: olhar crítico sobre monitoramento de políticas públicas. - 1. ed. - Rio de Janeiro: Ford Foundation, 2011. 
Anexo 1: Matrículas por conveniamento total do estado do Rio de Janeiro, divididas por Mesorregiões e pela Baixada Fluminense, de 2008 a 2019

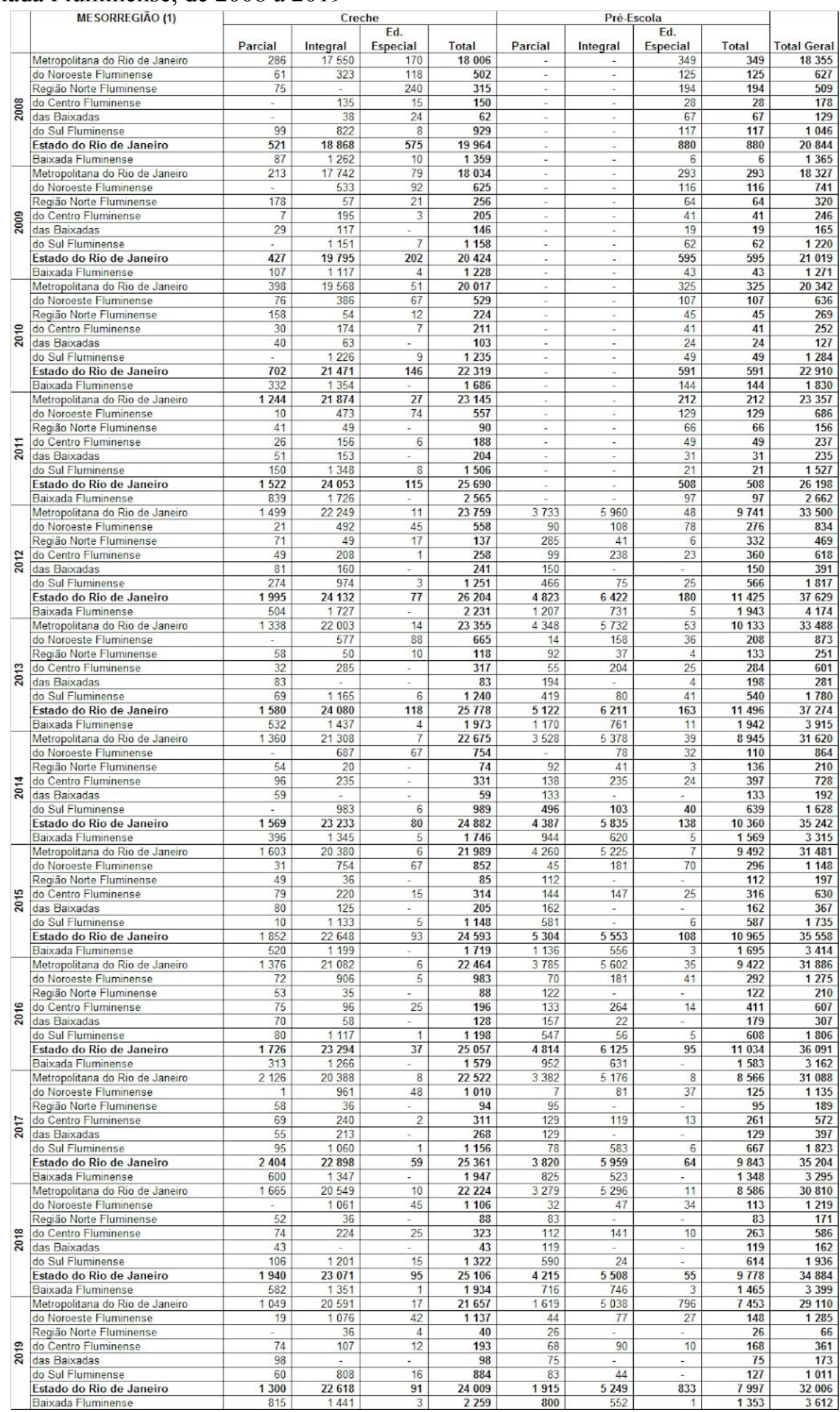

Fonte: Tabulação Própria, com base: MEC/Fundo Nacional de Desenvolvimento da Educação - FNDE/Fundo de Manutenção e Desenvolvimento da Educação Básica e de Valorização dos Profissionais da Educação Fundeb, 2008 a 2019. 